Gut, 1978, 19, 1125-1130

\title{
Renal clearance of pancreatic and salivary amylase relative to creatinine in patients with chronic renal insufficiency
}

\author{
J. B. KEOGH', K. F. McGeENEY, M. I. DRURY, T. B. COUNIHAN, AND \\ MARY D. O'DONNELL \\ From the Department of Medicine, Mater Hospital, and Department of Medicine and Therapeutics, \\ University College, Dublin
}

SUMMARY Pancreatic and salivary amylase/creatinine clearance ratios in patients with various degrees of renal impairment were compared with those obtained for control subjects. In chronic renal insufficiency (mean GFR $30 \mathrm{ml} / \mathrm{min} \pm 15 \mathrm{SD} ; \mathrm{n}=13$ ) the clearance ratios for pancreatic (mean $3.5 \pm 1.85 \mathrm{SD}$ ) and salivary (mean $2.3 \pm 1.3 \mathrm{SD})$ amylase were significantly higher $(\mathrm{P}<0.05)$ than those in controls. Corresponding control values $(n=26)$ were $2.64 \pm 0.86$ (pancreatic) and $1.64 \pm 0.95$ (salivary). Three patients showed values above the normal limit. In the diabetic group (mean GFR $41 \mathrm{ml} / \mathrm{min} \pm 22 \mathrm{SD} ; \mathrm{n}=10$ ) salivary amylase/creatinine clearance ratios (mean $2 \cdot 36 \pm$ $1.55 \mathrm{SD})$ were significantly higher than in controls $(\mathrm{P}<0.05)$. Three patients showed raised values. Pancreatic amylase clearance was raised in only one of these patients. Three patients with terminal disease (mean GFR $10 \mathrm{ml} / \mathrm{min}$ ) showed markedly raised (two- to threefold) clearance ratios for both salivary and pancreatic amylase. Of a total of 26 patients, eight had increased total amylase/creatinine clearance ratios. Pancreatic amylase/creatinine clearance was increased in seven patients, while nine patients showed raised salivary amylase/creatinine ratios. Patients with raised clearance ratios did not have clinical evidence of pancreatitis. We suggest that, in the presence of impaired renal function, a high amylase/creatinine clearance ratio need not be indicative of pancreatic disease.

The amylase (am)/creatinine (cr) clearance $(\mathrm{C})$ ratio $\left(\mathrm{C}_{\mathrm{am}} / \mathrm{C}_{\mathrm{er}}\right)$ has been suggested as a useful aid in diagnosing acute pancreatitis in patients with renal insufficiency (Levitt et al., 1969). Some authors have reported that the ratio $\mathrm{C}_{\mathrm{am}} / \mathrm{C}_{\mathrm{cr}}$ remains normal in renal insufficiency (Blainey and Northam, 1967; Levitt $e$ t al., 1969) and is increased in the presence of pancreatitis (Mulhausen et al., 1969; Drieling et al. 1974; Warshaw and Fuller, 1975). In contrast, recent, studies (Morton et al., 1976; Lankisch et al., 1977) have found raised $C_{a m} / C_{c r}$ ratios in patients with chronic renal failure without accompanying pancreatitis. These studies measured the clearance of total (T) amylase. In investigating this problem we studied the clearance of both pancreatic (P) and salivary (S)type amylase in 15 patients with chronic renal insufficiency (CRI) and 11 with diabetes mellitus (DM), all with impaired renal function.

1Present address: Meath Hospital, Dublin 8.

Received for publication 31 July 1978

\section{Methods}

PATIENTS

Twenty-six patients were divided into three groups as follows: (1) 13 patients with intrinsic renal disease. Their clinical diagnoses are outlined in Table 1. (2) Ten insulin dependent diabetic patients with chronic renal insufficiency. Details of this group are included in Table 2. (3) Three patients with terminal disease are shown in Table 3. Two of these had terminal renal failure one of whom was a diabetic; the third patient had terminal heart failure.

All patients in Tables 1 and 2 were clinically stable and had no clinical evidence of pancreatitis. The diabetic population were all controlled with monocomponent insulins; one had ketoacidosis.

Control subjects $(n=26)$ comprised 12 males and 14 females (age range 19-70 years). These included 14 healthy volunteers and 12 hospital controls who showed no evidence of parotid, abdominal, or renal disease. 
Table 1 Patients with chronic renal insufficiency

\begin{tabular}{|c|c|c|c|c|c|c|c|c|c|c|}
\hline \multirow[t]{2}{*}{ Name } & \multirow[t]{2}{*}{ Age $(y r)$} & \multirow[t]{2}{*}{$\operatorname{Sex}$} & \multirow[t]{2}{*}{ Diagnosis } & \multicolumn{3}{|c|}{ Serum amylase $(U / L)$} & \multirow{2}{*}{$\begin{array}{l}\text { GFR } \\
(\mathrm{ml} / \mathrm{min})\end{array}$} & \multicolumn{3}{|c|}{$C_{a m} / C_{c r}(\%)$} \\
\hline & & & & $\boldsymbol{T}$ & $s$ & $\boldsymbol{P}$ & & $T$ & $S$ & $\boldsymbol{P}$ \\
\hline $\begin{array}{l}\text { M. F. } \\
\text { E. R. }\end{array}$ & $\begin{array}{l}23 \\
47\end{array}$ & $\begin{array}{l}\mathbf{M} \\
\mathbf{M}\end{array}$ & $\begin{array}{l}\text { Chronic interstitial nephritis* } \\
\text { Cirrhosis; CCF; COAD; HT; } \\
\text { nephrotic syndrome* }\end{array}$ & $\begin{array}{l}400 \\
170\end{array}$ & $\begin{array}{r}166 \\
81\end{array}$ & $\begin{array}{r}234 \\
89\end{array}$ & $\begin{array}{l}16.0 \\
21.0\end{array}$ & $\begin{array}{l}3.7 \\
5.0\end{array}$ & $\begin{array}{l}2 \cdot 8 \\
4 \cdot 07\end{array}$ & $\begin{array}{l}4 \cdot 4 \\
5 \cdot 4\end{array}$ \\
\hline $\begin{array}{l}\text { E. F. } \\
\text { M. R. }\end{array}$ & $\begin{array}{l}67 \\
64\end{array}$ & $\begin{array}{l}\mathbf{M} \\
\mathbf{F}\end{array}$ & $\begin{array}{l}\text { Chronic pyelonephritis } \\
\text { Chronic pyelonephritis, rheumatoid } \\
\text { arthritis }\end{array}$ & $\begin{array}{l}470 \\
360\end{array}$ & $\begin{array}{l}100 \\
146\end{array}$ & $\begin{array}{l}370 \\
214\end{array}$ & $\begin{array}{r}20 \cdot 4 \\
7 \cdot 8\end{array}$ & $\begin{array}{l}1 \cdot 18 \\
3 \cdot 25\end{array}$ & $\begin{array}{l}0.88 \\
2.92\end{array}$ & $\begin{array}{l}1.26 \\
3.5\end{array}$ \\
\hline $\begin{array}{l}\text { K. D. } \\
\text { T. H. }\end{array}$ & $\begin{array}{l}48 \\
68\end{array}$ & $\begin{array}{l}\mathbf{F} \\
\mathbf{M}\end{array}$ & $\begin{array}{l}\text { Chronic obstructive uropathy } \\
\text { Coronary insufficiency; } \\
\text { nephrosclerosis }\end{array}$ & $\begin{array}{l}640 \\
310\end{array}$ & $\begin{array}{l}131 \\
200\end{array}$ & $\begin{array}{l}509 \\
110\end{array}$ & $\begin{array}{l}12 \cdot 3 \\
22 \cdot 0\end{array}$ & $\begin{array}{l}2.9 \\
1.44\end{array}$ & $\begin{array}{l}0.97 \\
1.2\end{array}$ & $\begin{array}{l}3.35 \\
1.9\end{array}$ \\
\hline $\begin{array}{l}\text { E. B. } \\
\text { F. S. } \\
\text { E. M. } \\
\text { M. R. } \\
\text { T. L. } \\
\text { W. O'D. }\end{array}$ & $\begin{array}{l}74 \\
62 \\
67 \\
84 \\
72 \\
57\end{array}$ & $\begin{array}{l}\mathbf{F} \\
\mathbf{M} \\
\mathbf{M} \\
\mathbf{M} \\
\mathbf{M} \\
\mathbf{M}\end{array}$ & $\begin{array}{l}\text { Hypernephroma* } \\
\text { Gouty nephropathy; myxodema* } \\
\text { Hypernephroma; haematuria } \\
\text { Nephrosclerosis } \\
\text { Tumour of kidney; Hypernephroma* } \\
\text { Nephrotic syndrome; membraneous } \\
\text { nephritis* }\end{array}$ & $\begin{array}{r}168 \\
205 \\
110 \\
155 \\
98 \\
275\end{array}$ & $\begin{array}{l}88 \\
42 \\
54 \\
24 \\
36 \\
86\end{array}$ & $\begin{array}{r}80 \\
163 \\
56 \\
131 \\
62 \\
189\end{array}$ & $\begin{array}{l}30 \cdot 2 \\
42 \cdot 0 \\
53 \cdot 0 \\
56 \cdot 0 \\
42 \cdot 5 \\
32 \cdot 6\end{array}$ & $\begin{array}{l}2 \cdot 34 \\
2 \cdot 7 \\
2 \cdot 8 \\
2 \cdot 95 \\
5 \cdot 2 \\
6 \cdot 3\end{array}$ & $\begin{array}{l}1 \cdot 7 \\
2 \cdot 0 \\
2 \cdot 7 \\
1 \cdot 56 \\
2 \cdot 85 \\
5 \cdot 1\end{array}$ & $\begin{array}{l}2.04 \\
2.9 \\
2.95 \\
3.0 \\
6.6 \\
6.9\end{array}$ \\
\hline K. D. & 67 & $\mathbf{F}$ & Rheumatic heart disease - CCF & 140 & 39 & 101 & $33 \cdot 4$ & $1 \cdot 18$ & 0.98 & $1 \cdot 26$ \\
\hline
\end{tabular}

CCF : congestive cardiac failure. COAD: chronic obstructive airways disease. HT: hypertension. *Histological diagnosis.

Table 2 Diabetic patients with renal insufficiency

\begin{tabular}{|c|c|c|c|c|c|c|c|c|c|}
\hline \multirow[t]{2}{*}{ Name } & \multirow[t]{2}{*}{ Age (yr) } & \multirow[t]{2}{*}{ Sex } & \multicolumn{3}{|c|}{ Serum amylase $(U / l)$} & \multirow{2}{*}{$\begin{array}{l}G F R \\
(m l / m i n)\end{array}$} & \multicolumn{3}{|c|}{$C_{a m} / C_{c r}(\%)$} \\
\hline & & & $T$ & $S$ & $\boldsymbol{P}$ & & $T$ & $S$ & $\boldsymbol{P}$ \\
\hline $\begin{array}{l}\text { M. D. } \\
\text { P. F. } \\
\text { P. D. } \\
\text { M. G. } \\
\text { F. M. } \\
\text { D. H. } \\
\text { C. K. } \\
\text { E. C. } \\
\text { J. H. } \\
\text { J. K. }\end{array}$ & $\begin{array}{l}72 \\
77 \\
64 \\
55 \\
26 \\
35 \\
23 \\
67 \\
77 \\
21\end{array}$ & $\begin{array}{l}\mathbf{M} \\
\mathbf{M} \\
\mathbf{M} \\
\mathbf{M} \\
\mathbf{M} \\
\mathbf{M} \\
\mathbf{F} \\
\mathbf{F} \\
\mathbf{M} \\
\mathbf{M}\end{array}$ & $\begin{array}{r}286 \\
480 \\
182 \\
133 \\
90 \\
180 \\
140 \\
120 \\
185 \\
47\end{array}$ & $\begin{array}{r}87 \\
235 \\
58 \\
62 \\
49 \\
77 \\
89 \\
44 \\
93 \\
28\end{array}$ & $\begin{array}{r}196 \\
245 \\
124 \\
71 \\
41 \\
103 \\
51 \\
76 \\
92 \\
19\end{array}$ & $\begin{array}{l}20 \cdot 8 \\
23 \cdot 9 \\
57 \\
47 \cdot 6 \\
81 \\
15 \cdot 45 \\
48 \\
17 \cdot 5 \\
60 \\
36 \cdot 8\end{array}$ & $\begin{array}{l}5 \cdot 2 \\
2 \cdot 6 \\
1 \cdot 48 \\
2 \cdot 2 \\
1 \cdot 65 \\
3 \cdot 85 \\
2 \cdot 78 \\
1 \cdot 48 \\
2 \cdot 92 \\
4 \cdot 0\end{array}$ & $\begin{array}{l}4.66 \\
0.96 \\
0.97 \\
2.07 \\
1.95 \\
3.88 \\
1.8 \\
1 \cdot 34 \\
2.0 \\
4.0\end{array}$ & $\begin{array}{l}5.5 \\
3.95 \\
1.74 \\
2.4 \\
0.97 \\
3.82 \\
4.5 \\
1.56 \\
3.85 \\
3.65\end{array}$ \\
\hline
\end{tabular}

Upper normal limits for $C_{\mathrm{sm}} / \mathrm{C}_{\mathrm{er}}$ (calculated as mean $+2 \mathrm{SD}, \mathrm{n}=26$; see Table 5 ) are $\mathrm{C}_{\mathrm{T}} / \mathrm{C}_{\mathrm{er}}=3.8 \%, \mathrm{C}_{\mathrm{a}} / \mathrm{C}_{\mathrm{er}}=3.5 \%$, and $\mathrm{C}_{\mathrm{p}} / \mathrm{C}_{\mathrm{er}}=4.4 \%$

Table 3 Patients with terminal disease

\begin{tabular}{|c|c|c|c|c|c|c|c|c|c|c|}
\hline \multirow[t]{2}{*}{ Name } & \multirow[t]{2}{*}{ Age (yr) } & \multirow[t]{2}{*}{$\operatorname{Sex}$} & \multirow[t]{2}{*}{ Diagnosis } & \multicolumn{3}{|c|}{ Serum amylase $(U / L)$} & \multirow{2}{*}{$\begin{array}{l}G F R \\
(\mathrm{ml} / \mathrm{min})\end{array}$} & \multicolumn{3}{|c|}{$C_{a m} / C_{c r}(\%)$} \\
\hline & & & & $T$ & $S$ & $\boldsymbol{P}$ & & $T$ & $S$ & $\boldsymbol{P}$ \\
\hline W. L. & 63 & $\mathbf{M}$ & $\begin{array}{l}\text { Chronic glomerulo- } \\
\text { nephritis* }\end{array}$ & 340 & 74 & 266 & $3 \cdot 4$ & $9 \cdot 0$ & $13 \cdot 3$ & $7 \cdot 7$ \\
\hline $\begin{array}{l}\text { E. D. } \\
\text { M. L. }\end{array}$ & $\begin{array}{l}22 \\
46\end{array}$ & $\begin{array}{l}\mathbf{M} \\
\mathbf{M}\end{array}$ & $\begin{array}{l}\text { Diabetic* } \\
\text { Acute bacterial endo- } \\
\text { carditis } \dagger\end{array}$ & $\begin{array}{l}140 \\
165\end{array}$ & $\begin{array}{l}63 \\
31\end{array}$ & $\begin{array}{r}77 \\
134\end{array}$ & $\begin{array}{r}4 \cdot 7 \\
21 \cdot 5\end{array}$ & $\begin{array}{l}9 \cdot 4 \\
9 \cdot 5\end{array}$ & $\begin{array}{l}10 \cdot 5 \\
14 \cdot 2\end{array}$ & $\begin{array}{l}8 \cdot 6 \\
8 \cdot 4\end{array}$ \\
\hline
\end{tabular}

* Terminal renal failure. $\dagger$ Terminal cardiac failure.

ANALYSES

A 24-hour urine sample was collected from all patients; blood was taken within this time interval. Each urine sample was measured for total volume and two $5 \mathrm{ml}$ aliquots retained for amylase and creatinine determination. Albumin was added to the samples for amylase analysis $(1 \mathrm{mg} / \mathrm{ml}$ urine). Serum and urine samples were stored at $-20^{\circ} \mathrm{C}$ before analysis. Samples from control subjects were treated similarly. Storage times did not exceed five days for amylase and two weeks for creatinine. Pancreatic and salivary amylase were determined by the method of
O'Donnell et al. (1977) using an $\alpha$-amylase inhibitor ${ }^{1}$ prepared from wheat. The Phadebas blue starch method for amylase assay was standardised as described (O'Donnell et al., 1977). Albumin (7.4 $\mu \mathrm{M}$ ) was incorporated in the reaction mixture in the case of all urine analyses. Creatinine estimations were carried out using the creatinine Rapid Stat Kit (Pierce, Rockford, Illinois). The amylase/creatinine clearance ratio was expressed as a percentage and calculated from the equation:

'Patent applied for. 
$\mathrm{C}_{\mathrm{am}} / \mathrm{C}_{\mathrm{cr}}=\frac{\text { Urine amylase }}{\text { Serum amylase }} \times \frac{\text { Serum creatinine }}{\text { Urine creatinine }} \times 100$

Values for serum and urinary pancreatic or salivary amylase were inserted in the equation to give the clearance of pancreatic $\left(\mathrm{C}_{\mathrm{p}} / \mathrm{C}_{\mathrm{cr}}\right)$ or salivary $\left(\mathrm{C}_{\mathrm{s}} / \mathrm{C}_{\mathrm{cr}}\right)$ amylase respectively.

\section{NORMAL VALUES}

The normal limits for serum amylase (total, pancreatic, and salivary) were calculated from the data on 69 female and 72 male control sera (O'Donnell $e t$ al., 1977). The values which represent $95 \%$ confidence limits and were calculated after logarithmic transformation are as follows:

$\begin{array}{lcc}\text { Serum amylase }(\mathrm{u} / \mathrm{l}) & \text { Males } & \text { Females } \\ \text { Total } & 56-270 & 75-277 \\ \text { Pancreatic } & 37-162 & 52-175 \\ \text { Salivary } & 9-172 & 9-196\end{array}$

The amylase/creatinine clearance values for the control subjects showed no statistical difference between 12 males and 14 females and were grouped together for comparison purposes. The normal limits were taken as mean \pm 2 SD $(n=26)$. Statistical analyses were performed using the non-paired Student's $t$ test.

\section{Results}

Differential serum amylase values for the 13 patients with chronic renal insufficiency are shown in Table 1 together with the amylase/creatinine clearance values for total, salivary, and pancreatic amylase. The glomerular filtration rates (GFR) as measured by creatinine clearance are also given. These range from $7.8 \mathrm{ml} / \mathrm{min}$ to $56 \mathrm{ml} / \mathrm{min}$ (mean $30 \mathrm{ml} / \mathrm{min} \pm 15 \mathrm{SD}$ ). Six patients had total serum amylase values above our upper limit. Five of these patients had raised serum pancreatic amylase values with normal salivary levels. The sixth patient showed a raised serum salivary amylase. When this group of 13 patients was compared with 69 control subjects the serum salivary and pancreatic amylase levels were both significantly higher in the patients with chronic renal insufficiency (Table 4). Three of the 13 patients in Table 1 had abnormal total amylase/creatinine clearance ratios-that is, $>3.8 \%$. Salivary amylase clearance was increased-that is, $>3.5 \%$-in two and pancreatic amylase clearance was increased - that is, $>4.4 \%$-in all three patients. Taken as a group, the mean total amylase/creatinine clearance ratio was significantly higher in these 13 patients when compared with controls $(P<0.025)$ (Table 5). This was due to an increased clearance of both salivary and pancreatic components.

Data related to the diabetic population are shown in Table 2. The GFR ranged from 15 to $81 \mathrm{ml} / \mathrm{min}$ (mean $41 \mathrm{ml} / \mathrm{min} \pm 22 \mathrm{SD}$ ). Hyperamylasaemia was present in two of the 10 patients; in one case (M. D.) this was due to pancreatic amylase only, while in the other (P. F.) both pancreatic and salivary amylase levels were elevated. When compared with the control group serum salivary levels were significantly higher $(P<0.01)$ in the diabetic patients (Table 4).

Table 4 Serum amylase and creatinine levels in patients with renal insufficiency compared with controls

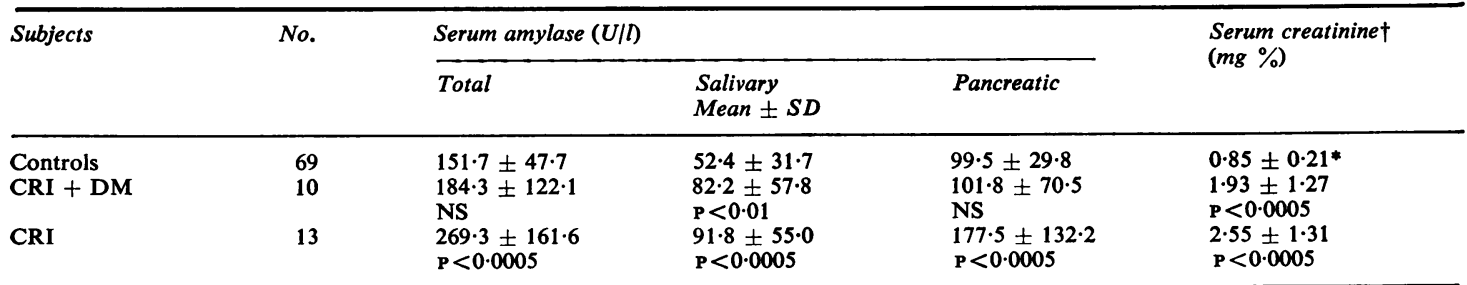

NS: not significant. *Creatinine values in patients are compared with 26 control sera. †For SI units multiply by 88.4 . Terminal patients not included in statistics.

Table 5 Data on amylase and creatinine excretion

\begin{tabular}{|c|c|c|c|c|c|c|c|}
\hline \multirow[t]{2}{*}{ Subjects } & \multirow[t]{2}{*}{ No. } & \multicolumn{3}{|c|}{$C_{a m} / C_{c r}(m e a n \pm S D(\%))$} & \multicolumn{3}{|c|}{ Urine Am/Urine $C r(\text { mean } \pm S D(U / m g))^{*}$} \\
\hline & & $T$ & $S$ & $\boldsymbol{P}$ & $T$ & $S$ & $\boldsymbol{P}$ \\
\hline $\begin{array}{l}\text { Controls } \\
\text { CRI + DM }\end{array}$ & $\begin{array}{l}26 \\
10\end{array}$ & $\begin{array}{l}2 \cdot 31 \pm 0.74 \\
2 \cdot 81 \pm 1.23 \\
\text { NS }\end{array}$ & $\begin{array}{l}1.64 \pm 0.95 \\
2.36 \pm 1.33 \\
P<0.05\end{array}$ & $\begin{array}{l}2.64 \pm 0.86 \\
3.19 \pm 1.44 \\
\text { NS }\end{array}$ & $\begin{array}{l}0.37 \pm 0.23 \\
0.35 \pm 0.30 \\
\text { NS }\end{array}$ & $\begin{array}{l}0.085 \pm 0.06 \\
0.11 \pm 0.05 \\
\mathrm{NS}\end{array}$ & $\begin{array}{l}0.28 \pm 0.20 \\
0.24 \pm 0.26 \\
\text { NS }\end{array}$ \\
\hline CRI & 13 & $\begin{array}{l}3.15 \pm 1.57 \\
P<0.025\end{array}$ & $\begin{array}{l}2.29 \pm 1.28 \\
P<0.05\end{array}$ & $\begin{array}{l}3.5 \pm 1.85 \\
P<0.05\end{array}$ & $\begin{array}{l}0.31 \pm 0.16 \\
\mathrm{NS}\end{array}$ & $\begin{array}{l}0.08 \pm 0.05 \\
\text { NS }\end{array}$ & $\begin{array}{l}0.23 \pm 0.13 \\
\mathrm{NS}\end{array}$ \\
\hline
\end{tabular}

NS : not significant. *For SI units $(\mathrm{U} / \mathrm{mmol})$ multiply by $0 \cdot 1131$. Terminal patients not included in statistics. 
Serum pancreatic amylase levels were not significantly different from controls. The salivary and pancreatic amylase/creatinine clearance ratios were raised in one patient (M. D.). Two additional patients (D. H. and J. K.) showed a marginal rise in salivary amylase/creatinine clearance. The mean total amylase/creatinine clearance ratio of the diabetic population was not significantly different from controls (Table 5). Examination of differential amylase clearance values in this same group shows the salivary amylase/creatinine clearance ratio to be significantly higher $(\mathrm{P}<0.05)$ compared with controls (Table 5). Mean pancreatic amylase/creatinine clearance ratios did not reach a level of significance. The quotient urinary amylase/urinary creatinine for both patient populations are also shown in Table 5 and compared with controls. No significant difference was noted.

Patients with terminal disease are summarised in Table 3. While only one patient showed hyperamylasaemia all three patients had markedly increased clearance of both salivary and pancreatic amylase.

The significantly increased rate of pancreatic amylase clearance relative to salivary amylase clearance $(P<0.0005)$ in control subjects has already been reported (Hegarty et al., 1978). This degree of preferential clearance of pancreatic relative to salivary amylase is markedly reduced in patients with renal insufficiency (Tables 3 and 6).

\section{Discussion}

This present study has demonstrated that, of 15 patients with chronic renal insufficiency, 10 showed normal clearance ratios for both salivary and pancreatic amylase. Of the remaining five patients, two had terminal disease and two had nephrotic syndrome, all with increased salivary and pancreatic amylase/creatinine clearance ratios. The fifth patient had hypernephroma and showed a high clearance ratio for pancreatic amylase only. It would appear that in terminal disease associated with renal failure a high amylase/creatinine clearance ratio need not indicate pancreatic disease. Post-mortem studies in two terminal patients failed to show evidence of pancreatitis. The two patients with nephrotic syndrome are of definite interest, as their high clearance values may well be related to the heavy proteinuria present. The reason for the high pancreatic amylase clearance ratio in the hypernephroma patient is unclear; the capacity of certain tumours to produce amylase has been described (Ammann et al., 1973; Berk and Fridhandler, 1975).

Eight of the 11 diabetic patients showed normal clearance values. Of the remaining three, one had terminal renal failure (GFR $5 \mathrm{ml} / \mathrm{min}$ ) with increased clearance ratio of both salivary and pancreatic amylase. One patient was mildly ketoacidotic and showed a raised clearance ratio for salivary amylase only. The explanation for the increased salivary amylase clearance ratio in the third patient is not clear.

The precise mechanisms of amylase transfer within the kidney have not yet been clarified. It was earlier concluded that amylase clearance was essentially a function of glomerular filtration without significant tubular reabsorption (McGeachin and Hargan, 1956; 1957; Duane et al., 1971). Recent work by Johnson et al. (1976) provides strong evidence in favour of tubular reabsorption of amylase in man. This has also been shown experimentally in the rat (Noda, 1972; Fredriksson and Jacobson, 1974). The more rapid clearance of pancreatic amylase relative to salivary amylase (Duane et al., 1972; Takeuchi et al., 1974; Fridhandler et al., 1972; Long and Grider, 1976; Hegarty et al., 1978) may be related to a more active reabsorption of salivary amylase by the proximal or distal tubule. Loss of this preferential clearance of pancreatic amylase relative to salivary amylase is evident in renal insufficiency (Tables 3 and 6) and is undoubtedly related to the accompanying renal tubular atrophy. Loss of tubular function would also explain why both salivary and pancreatic amylase/creatinine clearance ratios are sometimes raised in renal disease. Acute pancreatitis, which is accompanied by renal tubular dysfunction, also leads to increased clearance ratios for both salivary and pancreatic amylase (Johnson et al., 1976). Interestingly, in chronic pancreatitis, where tubular function is not impaired, as evidenced by normal clearance of $\beta_{2}$-microglobulin, $\mathrm{C}_{\mathrm{p}} / \mathrm{C}_{\mathrm{cr}}$ only is raised (Hegarty et al., 1978).

Table 6 Renal clearance of pancreatic amylase compared with salivary amylase in renal insufficiency

\begin{tabular}{lllll}
\hline Subjects & No. & \multicolumn{1}{l}{$C_{s} / C_{c r}$} & $C_{p} / C_{e r}$ & \multirow{2}{*}{$C_{p}$ compared with $C_{s}^{*}$} \\
\cline { 2 - 4 } & & Mean $\pm S D(\%)$ & \\
\hline Controls & 26 & $1.64 \pm 0.95$ & $2.64 \pm 0.86$ & $\mathrm{P}<0.0005$ \\
CRI + DM & 10 & $2.36 \pm 1.33$ & $3.19 \pm 1.44$ & $\mathrm{P}<0 \cdot 15$ \\
CRI & 13 & $2.29 \pm 1.28$ & $3.5 \pm 1.85$ & $\mathrm{P}<0.05$ \\
\hline
\end{tabular}

* $t$ test. Terminal patients not included. 
Our study demonstrates a rise of both salivary and pancreatic amylase in the serum of patients with chronic renal insufficiency compared with controls. This increase ( $\sim$ two fold) is less than the corresponding rise in serum creatinine ( $\sim$ three fold) (Table 4). Since the quotient urinary amylase/ urinary creatinine is not significantly higher in patients with chronic renal insufficiency relative to controls (Table 5), the increased $\mathrm{C}_{\mathrm{am}} / \mathrm{C}_{\mathrm{cr}}$ ratio must also be related to the greater rise in serum creatinine than in serum amylase (see clearance equation).

This finding of an increased amylase/creatinine clearance ratio in some patients with chronic renal insufficiency agrees with the results of Morton et al. (1976) and Lankisch et al. (1977). A high amylase/ creatinine clearance ratio has also been reported in severe renal failure (GFR less than $25 \mathrm{ml} / \mathrm{min}$ ) by Pedersen et al. (1976). The severity of renal insufficiency may explain why the results differ from those previously reported (Blainey and Northam, 1967; Levitt et al., 1969).

The majority of our patients with chronic renal insufficiency had normal amylase/creatinine clearance ratios. Warshaw (1976) has suggested that perhaps the most assured use of the amylase/creatinine clearance ratio will be when it is not raised, thereby excluding pancreatitis. The validity of this suggestion appears doubtful in view of the recent report (Dürr et al., 1977) that some patients with acute pancreatitis have normal $\mathrm{C}_{\mathrm{am}} / \mathrm{C}_{\mathrm{cr}}$ ratios.

Our results show that the increased amylase/ creatinine clearance ratio in chronic renal insufficiency could be due to both salivary and pancreatic amylase. The clearance ratio should therefore be interpreted with caution in the presence of severe renal insufficiency. A high ratio need not be indicative of pancreatitis, since our patients had no clinical evidence of exocrine pancreatic disease and were not on drugs which could cause hyperamylasaemia.

We are indebted to the Medical Research Council of Ireland for financial support. We also thank Miss D. Osborne for her help in preparing the manuscript.

\section{References}

Ammann, R. W., Berk, J. E., Fridhandler, L., Ueda, M., and Wegmann, W. (1973). Hyperamylasemia with carcinoma of the lung. Annals of Internal Medicine, 78, 521-525.

Berk, J. E., and Fridhandler, L. (1975). Clinical application of amylase isoenzyme analysis. American Journal of Gastroenterology, 63, 457-463.

Blainey, J. D., and Northam, B. E. (1967). Amylase excretion by the human kidney. Clinical Science, 32, 377-383.

Dreiling, D. A., Leichtling, J. J., and Janowitz, H. D. (1974). The amylase/creatinine clearance ratio: Diagnostic parameter or physiologic phenomenon? American Journal of
Gastroenterology, 61, 290-296.

Duane, W. C., Frerichs, R., and Levitt, M. D. (1971). Distribution, turnover, and mechanism of renal excretion of amylase in the baboon. Journal of Clinical Investigation, 50, 156-165.

Duane, W. C., Frerichs, R., and Levitt, M. D. (1972). Simultaneous study of the metabolic turnover and renal excretion of salivary amylase $-{ }^{125} \mathrm{I}$ and pancreatic amylase - ${ }^{131}$ I in the baboon. Journal of Clinical Investigation, 51, 1504-1513.

Dürr, H. K., Bode, J. C., Lankisch, P. G., and Koop, H. (1977). Amylase-creatinine clearance ratio in pancreatitis (Letter). New England Journal of Medicine, 296, 635.

Fredriksson, A., and Jacobson, G. (1974). Influence of renal function on the urinary excretion of amylase: An experimental study in the rat. Scandinavian Journal of Clinical Laboratory Investigation, 33, 313-321.

Fridhandler, L., Berk, J. E., and Ueda, M. (1972). Isolation and measurement of pancreatic amylase in human serum and urine. Clinical Chemistry, 18, 1493-1497.

Hegarty, J. E., O'Donnell, M. D., McGeeney, K. F., and FitzGerald, O. (1978). Pancreatic and salivary amylase/ creatinine clearance ratios in normal subjects and in patients with chronic pancreatitis. Gut, 19, 350-354.

Johnson, S. G., Ellis, C. J., and Levitt, M. D. (1976). Mechanism of increased renal clearance of amylase/creatinine in acute pancreatitis. New England Journal of Medicine, 295, 1214-1217.

Lankisch, P. G., Wolfrum, D. I., Koop, H., and Winckler, K. (1977). Amylase/creatinine clearance ratio $\left(C_{a m} / C_{c r}\right)$ and renal tubular function in acute pancreatitis (AP): Lack of specificity. Irish Journal of Medical Science, 146, Suppl. $1,28$.

Levitt, M. D., Rapoport, M., and Cooperband, S. R. (1969). The renal clearance of amylase in renal insufficiency, acute pancreatitis, and macroamylasemia. Annals of Internal Medicine, 71, 919-925.

Long, W. B., and Grider, J. R., (1976). Amylase isoenzyme clearances in normal subjects and in patients with acute pancreatitis. Gastroenterology, 71, 589-593.

McGeachin, R. L., and Hargan, L. A. (1956). Renal clearance of amylase in man. Journal of Applied Physiology, 9, 129-131.

McGeachin, R. L., and Hargan, L. A. (1957). Amylase clearance and excretion during water diuresis. Proceedings of the Society of Experimental Biology and Medicine, 95, 341-343.

Morton, W. J., Tedesco, F. J., Harter, H. R., and Alpers, D. H. (1976). Serum amylase determinations and amylase to creatinine clearance ratios in patients with chronic renal insufficiency. Gastroenterology, 71, 594-598.

Mulhausen, R., Brown, D. C., and Onstad, G. (1969). Renal clearance of amylase during pancreatitis. Metabolism, 18, 669-674.

Noda, A. (1972). Renal handling of amylase: Evidence for reabsorption by stop-flow analysis. Metabolism, 21, 351-355.

O'Donnell, M. D., FitzGerald, O., and McGeeney, K. F. (1977). Differential serum amylase determination by use of an inhibitor, and design of a routine procedure. Clinical Chemistry, 23, 560-566.

Pedersen, E. B., Brock, A., and Kornerup, H. J. (1976). Serum amylase activity and renal amylase clearance in patients with severely impaired renal function and in patients treated with renal allotransplantation. Scandinavian Journal of Clinical Laboratory Investigation, 36, 137-140.

Takeuchi, T., Matsushima, T., Sugimara, T., Kozu, T., Takeuchi, T., and Takemoto, T. (1974). A rapid new method for quantitative analysis of human amylase isozymes. 
Clinica Chimica Acta, 54, 137-144.

Warshaw, A. L. (1976). The kidney and changes in amylase clearance. Gastroenterology, 71, 702-704.

Warshaw, A. L., and Fuller, A. F., Jr. (1975). Specificity of increased renal clearance of amylase in diagnosis of acute pancreatitis. New England Journal of Medicine, 292, 325-328.

\section{The November 1978 Issue}

\section{THE NOVEMBER 1978 ISSUE CONTAINS THE FOLLOWING PAPERS}

Effects of cerebral oedema and arterial hypotension on cerebral blood flow in an animal model of hepatic failure P. N. TREWBY, M. A. HANID, R. L. MACKENZIE, P. J. MELLON, AND ROGER WILLIAMS

Diurnal serum levels of primary conjugated bile acids. Assessment by specific radioimmunoassays for conjugates of cholic and chenodeoxycholic acid S. W. SCHALM, N. F. LARUSSO, A. F. HOFFMANN, N. E. HOFFMAN, G. P. VAN BERGE-HENEGOUWEN, AND M. G. KORMAN

Portal fibrosis in the livers of alcoholic patients MARSHA Y. MORGAN, SHEILA SHERLOCK, AND P. J. SCHEUER

Hepatocellular carcinoma in Great Britain: influence of age, sex, HBsAg status, and aetiology of underlying cirrhosis P. J. JOHNSON, N. KRASNER, B. PORTMANN, A. L. W. F. EDDLESTON, AND ROGER WILLIAMS

Ultrasonic scanning in pancreatic disease J. G. B. RUSSELL, A. G. VALLON, JOAN M. BRAGANZA, AND H. T. HOWAT

Mucosal-associated bacterial flora of the intestine in patients with Crohn's disease and in a control group SUSAN PEACH, M. R. LOCK, D. KATZ, I. P. TODD, AND SOAD TABAQCHALI

Measurement of fasting and postprandial plasma VIP in man S. J. MITCHELL AND S. R. BLOOM
Vasoactive intestinal peptide in man: pharmacokinetics, metabolic and circulatory effects $s$. DOMSCHKE, W. DOMSCHKE, S. R. BLOOM, P. MITZNEGG, S. J. MTTCHELL, G. LUX, AND U. STRUNZ

Prevalence of diverticular disease of the colon in patients with ischaemic heart disease K. J. FOSTER, G. HOLDSTOCK, P. J. WHORWELL, P. GUYER, AND RALPH WRIGHT

Venous prostaglandin-like activity in diarrhoeal states D. W. HARRIS, C. H. J. SWAN, AND P. R. SMITH

Histamine receptors in the gastric microcirculation P. H. GUTH AND ESTHER SMITH

Is hypergastrinaemia associated with rheumatoid arthritis? D. R. ROWDEN, I. L. TAYLOR, J. A. RICHTER, R. S. PINALS, AND R. A. LEVINE

Plasma ratio of valine, leucine and isoleucine to phenylalanine and tyrosine in liver disease MARSHA Y. MORGAN, JUDITH P. MILSON, AND SHEILA SHERLOCK

Progress report Dietary lactose and the aetiology of human small-intestinal hypolactasia T. SAHI

Notes and activities

Books

Copies are still available and may be obtained from the PUBLISHING MANAGER, BRITISH MEDICAL ASSOCIATION, TAVISTOCK SQUARE, WC1H 9JR, price $£ 2.75$, including postage 